\title{
MODELS OF FUTURE MANAGERS PREPARATION \\ TO THE APPLICATION OF PEDAGOGICAL \\ MANAGEMENT TECHNOLOGIES
}

\section{МОДЕЛЬ СИСТЕМИ ПІДГОТОВКИ \\ МАЙБУТНІХ КЕРІВНИКІВ ДО ЗАСТОСУВАННЯ \\ ТЕХНОЛОГІЙ ПЕДАГОГІЧНОГО МЕНЕДЖМЕНТУ}

\section{Marianna Shvardak ${ }^{1}$}

DOI: https://doi.org/10.30525/978-9934-26-021-6-8

Abstract. Subject of research: the system of preparation of future managers for the application of pedagogical management technologies. The survey used online survey, scaling and ranking methods. The purpose of the study: to outline the structural and functional model of the system of training future heads of general secondary education institutions to use the technologies of pedagogical management. the structural-functional model of the system of preparation of future managers for the application of pedagogical management technologies is presented, the main structural blocks and the nature of their interaction are outlined. It was found that the target block of the presented model is system-forming, as it reflects the purpose and leading tasks of the system of training future managers, which serve as a basis for determining the content, organizational forms, methods and means of forming readiness to apply pedagogical management technologies. The methodological block, in turn, reveals a system of eponymous approaches and principles (general didactic and specific), which became the scientific basis for defining and implementing pedagogical conditions, structuring the content of the system of training future leaders to use pedagogical management technologies, optimal choice of forms, methods and teaching aids. activities. The content block is determined by the educational program, curricula, programs, textbooks,

\footnotetext{
${ }^{1}$ Candidate of Pedagogical Sciences, Associate Professor, Associate Professor of Pedagogy, Preschool,

Primary Education and Educational Management Department, Mukachevo State University, Ukraine
} 
manuals, modern scientific concepts and methodological developments in pedagogical technologies, which are essential for the formation of the ability of future leaders to apply pedagogical management technologies. The procedural block is characterized by the integrity and systematization of the educational process in terms of master's degree, ensuring the participation of the applicant in all activities. Implemented through the use of training and diagnostic technologies in the training system. The control unit reproduces the achievement of the goal, ie the end result of the process of preparing the future leader for the application of pedagogical management technologies the formation of this readiness. The proposed model corresponds to the identified trends in the coordination of changes in professional activities and the content of vocational education on the example of training future managers to use technologies of pedagogical management. The presented model can be considered as a basis of original strategy of professional education in the conditions of a magistracy, but at the same time, efficiency of its application needs to be checked in an experimental part of research for the further comprehension and adjustment.

\section{1. Вступ}

Проблема підготовки нової генерації менеджерів освіти, здатних позити-вно впливати на педагогічний колектив та здобувачів освіти, проєктувати та успішно реалізувати освітню політику відповідно до нових вимог, а відтак - оперувати системою технологій педагогічного менеджменту, є надзвичайно актуальною.

Процес формування готовності майбутнього керівника закладу освіти до застосування технологій педагогічного менеджменту розглядається нами як цілісна система підготовки здобувача вищої освіти в умовах магістратури. Вона відображає об'єктивні тенденції розвитку вищої освіти, закономірності управлінської діяльності, місць та роль керівника в ній, сукупність компетентностей та результатів навчання, перелік функцій управління, технологій педагогічного менеджменту, володіння якими є беззаперечною передумовою успішного управління закладом освіти [6].

Одним зі ефективних шляхів формування готовності майбутніх керівників $33 \mathrm{CO}$ до застосування технологій педагогічного менеджменту є розробка моделі, відповідно до якої має бути організована 
система підготовки на другому (магістерському) рівні в ЗВО за спеціальностями 073 «Менеджмент» та 011 «Освітні, педагогічні науки» (спеціалізація «Управління закладами освіти»).

Проблема педагогічного моделювання, створення моделей професійної підготовки майбутніх фахівців розробляється у працях науковців: С. Архангельський, Ю. Бабанського, В. Беспалько, С. Гончаренко, В. Кремень, О. Лебідь, І. Подласий, Н. Сас, М. Чеботарьов, В. Ягупов.

Мета дослідження - окреслення структурно-функціональної моделі системи підготовки майбутніх керівників $33 \mathrm{CO}$ до застосування технологій педагогічного менеджменту.

\section{2. Структура моделі, її мета та завдання}

В. Ягупов переконаний, що наявність науково обгрунтованої моделі дозволяє спрогнозувати розвиток педагогічного явища. Вважає, що «модель - знакова система, за допомогою якої можна відтворити дидактичний процес як предмет дослідження, показати в цілісності його структуру, функціонування й зберегти цю цілісність на всіх етапах дослідження» [8, с. 31].

Важливе значення для нашого дослідження має структурно-функціональна модель системи підготовки майбутніх керівників $33 \mathrm{CO}$ до застосування технологій педагогічного менеджменту. Під даним поняттям ми розуміємо розгорнуту програму дій (проєкт освітнього процесу в умовах магістратури), що включає шляхи досягнення поставленої мети та має певну структурну організацію в системі цілісної професійної підготовки.

В основі означеної моделі - багатокомпонентна, цілісна та логічна система, яка включає цільовий, методологічний, змістовий, процесуальний та контрольний блоки [2; 4]. Дієвість моделі системи підготовки забезпечують педагогічні умови. Визначені структурні блоки моделі та їх елементи спрямовані на формування належного рівня готовності майбутніх керівників $33 \mathrm{CO}$ до застосування технологій педагогічного менеджменту. Зупинимося на детальній характеристиці означених блоків розробленої моделі.

Цільовий блок структурно-функціональної моделі є системоутворюючим, оскільки відображає мету та провідні завдання системи підготовки майбутніх керівників 33СО, які слугують основою при визна- 
ченні змісту, організаційних форм, методів та засобів формування готовності до застосування технологій педагогічного менеджменту в умовах магістратури.

Мета виступає еталоном для моніторингу, контролю й оцінки досягнутих результатів навчання і дозволяє їх коригувати. Відтак, мета впровадження моделі - формування на належному рівні готовності майбутніх керівників закладів загальної середньої освіти до застосування технологій педагогічного менеджменту в процесі професійної підготовки. Досягненню цієї мети підпорядковані всі наступні компоненти моделі.

Мета визначає основні завдання формування готовності до застосування технологій педагогічного менеджменту: формування в здобувачів вищої освіти мотивації до ефективної управлінської діяльності; усвідомлення потреби в технологізації управлінської діяльності в 33СО; засвоєння теоретичних засад актуальних сучасних технологій педагогічного менеджменту; набуття вмінь та навичок ефективного використання технологій педагогічного менеджменту; вміння здійснювати оптимальний вибір технологій педагогічного менеджменту; формування у майбутніх керівників управлінсько-технологічної компетентності - здатності ефективно здійснювати технологізацію управлінської діяльності в закладах загальної середньої освіти.

Окрім того, мета впровадження моделі окреслює результат системи під-готовки - досягнення позитивної й стійкої динаміки в плані готовності майбутніх керівників до застосування технологій педагогічного менеджменту в 33СО, що дасть можливість успішно здійснювати управлінську діяльність, оперуючи, відповідно до ситуації, системою технологій педагогічного менеджменту.

\section{3. Методологічні підходи та принципи системи підготовки}

Методологічний блок моделі професійної підготовки розкриває систему однойменних підходів та принципів (загальнодидактичних та специфічних), які стали науковим підгрунтям для визначення та впровадження педагогічних умов, структурування змісту системи підготовки майбутніх керівників до застосування технологій педагогічного менеджменту, оптимального вибору форм, методів та засобів навчальної діяльності. 
Реалізація системи підготовки майбутніх керівників закладів освіти в умовах магістратури та формування в них готовності до застосування технологій педагогічного менеджменту вимагає ефективних методологічних підходів, що дозволяє зробити таку підготовку максимально ефективною, динамічною та гнучкою до змін в системі освіти. Першорядними методологічними підходами формування готовності майбутніх керівників закладів освіти до застосування технологій педагогічного менеджменту в умовах сьогодення, на нашу думку, $€$ : технологічний, компетентнісний, студентоцентрований, системний, діяльнісний, праксеологічний, ситуативний, диджиталізований, рефлексивний та ін. [6].

Методологія системи підготовки майбутніх керівників до застосування технологій педагогічного менеджменту реалізується також за умов дотримання системи принципів навчання, які є взаємообумовленими та взаємопов'язаними. У нашому дослідженні ми покладалися на систему загальнодидактичних та специфічних принципів.

Серед загальнодидактичних принципів виокремлюємо наступні: науковості, систематичності і послідовності, свідомості, наочності, активності, самостійності, опори на життєвий досвід, міцності знань.

Більш детальніше зупинимось на характеристиці специфічних принципів викладання технологічно-оріснтованої навчальної дисципліни «Технології педагогічного менеджменту».

Принцип практичної зорієнтованості - передбачає входження здобувачів вищої освіти через квазіпрофесійну та навчально-професійну у майбутню - професійну діяльність, орієнтовану на технологізацію управлінської діяльності в 33СО. Даний принцип визначає формування в професійно імітованих ситуаціях умінь та навичок із впровадження в 33СО технологізації управлінської діяльності, тренування в реалізації ефективних технологій педагогічного менеджменту; передбачає використання зразків передового інноваційного досвіду з оптимального вибору та використання технологій в управлінні $33 \mathrm{CO}$ під час проходження практики.

Принцип персоніфікованості передбачає організацію освітнього процесу 3 урахуванням індивідуальних особливостей здобувачів освіти, їх інтересів, мотивів, запитів, потреб, рівня здібностей при розробленні алгоритмів покрокового застосування технологій педагогіч- 
ного менеджменту та в процесі імітації процесу технологізації управлінської діяльності у 3ВО.

Принцип інтегративності означає взаємопроникнення та міждисциплінарну кооперацію навчальної інформації, що стосується технологій педагогічного менеджменту, організації іiі структурно-логічної взаємодоповнюваності та взаємозалежності в рамках навчальних дисциплін, що вивчаються майбутніми керівниками відповідно до освітньо-професійної програми. Практичне втілення принципу можливе за рахунок міждисциплінарної інтеграції; інтеграції теоретичного та практичного, аудиторного та позааудиторного навчання; інтеграції навчальних дисциплін із управлінською практикою та науково-дослідною діяльністю здобувача.

Принцип адаптованості та гнучкості означає таку побудову змісту освіти, за якою майбутній фахівець здатен опановувати нові технології педагогічного менеджменту, підвищувати свою кваліфікацію в мінливих умовах сьогодення, швидко реагувати на зміни в освіті, вміти оперативно адаптуватись до соціально-економічних потреб суспільства, бачити сучасні тенденції розвитку закладу освіти, вміти мобілізуватися в ситуаціях невизначеності, спрямувати у відповідному напрямку роботу педагогічного колективу. Майбутній керівник здобуває не тільки знання, вміння і навички 3 традиційних технологій педагогічного менеджменту, а й формує шлях до продукування нових, актуальних саме на даний час, технологій. Наприклад, в умовах локдауну керівникам необхідно було оперативно адаптуватись до карантинних умов і налагодити взаємодію із суб' єктами освітнього процесу через хмарні технології управління, завдяки яким можна було практично безперебійно реалізувати освітній процес в ЗЗСО. Практична реалізація цього принципу досягається через управлінську практику та тренінги 3 технологій педагогічного менеджменту.

Принцип фахової креативності передбачає здатність здобувача вийти $з$ добре пізнаного освітнього середовища та ввійти до нової професійної реальності. Практична реалізація принципу досягається через максимальну орієнтацію майбутнього керівника у системі його професійної підготовки на креативність. Мова йде про формування у нього здатності самостійно знаходити неординарні рішення завдань, 
«відкривати» нові способи дій, адаптовувати наявний та розробляти новий інструментарій технологій педагогічного менеджменту тощо.

Принцип інтерактивності вказує на відмову від репродуктивних тактик роботи 3 навчальним матеріалом та широке впровадження ситуативного моделювання й опрацювання дискусійних питань; ратує на реалізацію перманентної співпраці, інтерактивної взаємодії суб'єктів освітнього середовища, співнавчання та взаємонавчання, потребу в освітній рефлексії, налагодженні постійного фідбеку. Практична реалізація цього принципу досягається через використання в аудиторній та позааудиторній роботах парної, групової, колективної форм навчання, а також, як уже зазначалось, форм ситуативного моделювання та опрацювання дискусійних питань. Враховуючи специфіку навчання здобувачів освіти за спеціальностями 011 та 073 (поєднання магістрантами навчальної та професійної діяльності) та сучасні тенденції освітньої диджиталізації, доцільно активно використовувати інформаційно-цифрові технології задля тісної інтеракції суб'єктів освітнього процесу та безперебійної фахової підготовки в умовах магістратури.

Принцип рефлексії передбачає розвиток навичок самоаналізу, самоконтролю, самоуправління в процесі формування готовності майбутніх керівників до застосування технологій педагогічного менеджменту; вказує на підвищення особистісно-професійних ресурсів, на формування особистісної та соціальної відповідальності, стресостійкості.

Принцип толерантності означає створення в освітньому середовищі ЗВО атмосфери доброзичливості, терпимості, гуманності у взаємозв'язках «студент-студент», «викладач-студент», «керівник-студент», стимуляції спілкування, що дозволить підвищити емоційну стійкість, розвивати адекватну самооцінку, рефлексію та комунікативні здібності. Практична реалізація принципу можлива через низку позааудиторних заходів за участі викладачів, кураторів, психологічної служби університету тощо (тренінги в групах здобувачів, діагностичні дослідження особистісних якостей здобувачів освіти).

Принцип якості освіти вказує на здобуття майбутніми керівниками певного обсягу знань, умінь і навичок, досвіду діяльності необхідної якості, формування відповідного рівня управлінсько-технологічної компетентності. Практична реалізація цього принципу досягається через стимулювання та мотивацію, як здобувачів освіти зі сторони нау- 
ково-педагогічних працівників в опануванні знань, практичних умінь, навичок, так і науково-педагогічних працівників зі сторони керівництва ЗВО щодо методів та технологій викладання, залучення студентів до проєктів, грантів, конкурсів.

Принцип академічної доброчесності базується на згоді всіх учасників освітнього процесу ЗВО дотримуватися етичних правил під час навчання, викладання та провадження науково-дослідної діяльності 3 метою забезпечення довіри до результатів навчання та наукових досягнень. Практична реалізація принципу передбачає самостійне виконання здобувачами навчальних завдань в розрізі технологій педагогічного менеджменту; посилання на джерела інформації у разі використання ідей, тверджень, відомостей; надання достовірної інформації про результати власної навчальної чи наукової діяльності [7].

Отже, визначені принципи системи підготовки майбутніх керівників до застосування технологій педагогічного менеджменту в умовах магістратури становлять відкриту систему, яка може поповнюватися та розвиватися. Цілком очевидно, що ефективність фахової підготовки залежатиме від комплексної реалізації та взаємодії означених загальнодидактичних та специфічних принципів.

\section{4. Зміст системи підготовки}

Результати контент-аналізу освітньо-професійних програм підготовки майбутніх керівників закладів освіти за спеціальностями 011 - «Освітні, педагогічні науки» та 073 - «Менеджмент», які реалізуються у ЗВО України, свідчать про суттєві розбіжності в їх змісті та недостатню увагу розробників до технологізації управлінської діяльності [5, с. 9-14].

3 метою оптимального формування змісту освітньо-професійної програми (наповнення інваріативного та варіативного складових навчальних планів) з підготовки майбутніх керівників в умовах магістратури в Мукачівському державному університеті проводяться семінари, вебінари, мітапи за участі внутрішніх (науково-педагогічних працівників, які забезпечують викладання за ОПП та здобувачів ОПП) та зовнішніх стейкхолдерів (директорів, заступників директорів 33СО, випускників ОПП). Центральним методом даних заходів $є$ панельна дискусія, в ході якої стейкхолдери окреслюють свої пропозиції щодо 
модернізації змістового наповнення освітньо-професійної програми 3 підготовки майбутніх керівників закладів освіти.

Також проводилось онлайн-опитування керівників 33СО України в хмарному сервісі Google Forms стосовно доцільності та важливості використання в управлінській діяльності різних технологій педагогічного менеджменту. 3 цією метою нами розроблено анкету «Актуальність застосування в $33 \mathrm{CO}$ технологій педагогічного менеджменту». В опитуванні взяли участь 410 керівників 33СО (директори та заступники директорів) різних регіонів України.

За результатами анкетування з'ясовано, що значна більшість респонден-тів (68\%) знають про технології педагогічного менеджменту в $33 \mathrm{CO}$ та дотримуються думки, що за умови вмілого оперування технологіями педагогічного менеджменту $є$ висока ймовірність щодо підвищення результативності управлінської діяльності в 33СО. 24\% респондентів в управлінській діяльності використовують різні технології, проте не знали, що вони так називаються.

Сучасні керівники $33 \mathrm{CO}$ усвідомлюють важливість, необхідність і доцільність впровадження технологій педагогічного менеджменту. Найбільш використовуваними є такі технології: стратегічного менеджменту, прийняття управлінських рішень, моніторингу, хмарні технології, лідерства, ефективних комунікацій, делегування повноважень, тимбілдингу (командоутворення). Менш використовуваними $€$ : технології коучингу, антимобінгу, «public relations», файндрайзингу, фасилітації, SWOT-, SNW-, PEST-аналізи, тайм-менеджменту, кайдзен-технологія, внутрішнього маркетингу, технології антикризового управління. Варто зауважити, що після світового локдауну, спричиненого COVID-19, відношення керівників до хмарних технологій різко змінилося. Тепер - це є одна з найуживаніших технологій педагогічного менеджменту.

Результати опитування показали, що керівники закладів освіти використовують в управлінській діяльності різні технології педагогічного менеджменту. Це, в своє чергу, вказує на те, що в процесі підготовки майбутніх керівників особливу увагу необхідно приділити засвоєнню знань про технології педагогічного менеджменту та формуванню здатності їх до застосування, що має відображатися у змісті освітньо-професійної програми. 
Тобто, з вищесказаного випливає, що ядром системи підготовки майбутнього керівника в умовах магістратури має стати формування його готовності до застосування технологій педагогічного менеджменту, а відтак, формування управлінсько-технологічної компетентності, врахування відповідності тим компетенціям, які висуває управлінська діяльність до керівника на певному етапі розвитку суспільства. Саме тому, модернізація системи підготовки майбутнього керівника передбачає коригування змісту професійної освіти задля його відповідності сучасним освітнім реаліям. Модернізація сучасної освіти передбачає ii «вдосконалення $з$ метою встановлення відповідності новітнім потребам суспільства й виведення на новий більш якісний рівень» [3, с. 261]. Тобто система підготовки майбутніх освітніх керівників в умовах магістратури за спеціальностями 011 та 073 потребує систематичного оновлення, розвитку інноваційних технологій педагогічного менеджменту, вивчення успішного зарубіжного та вітчизняного менеджерського досвіду і трансформації його в систему освіти України.

Модернізація змісту системи підготовки майбутнього керівника (менеджера в системі освіти) в контексті нашого дослідження здійснюється за такими напрямами:

1. Коригування освітньо-професійної програми «Освітні, педагогічні науки» за спеціальністю 011 - «Освітні, педагогічні науки» (спеціалізація «Управління закладами освіти»), яка орієнтована на фахову підготовку майбутнього керівника (менеджера в системі освіти). Реалізується на базі Мукачівського державного університету. Дана програма у 2019 році акредитована Національним агентством із забезпечення якості вищої освіти (Рішення НАЗЯВО № 17(3.13) від 23.12.2019).

Оновлення робочого плану з означеної спеціальності з урахуванням потреби у готовності майбутнього керівника до застосування технологій педагогічного менеджменту.

2. Модифікація змісту навчальних дисциплін загального та професійного циклів інваріативної та варіативної складових ОПП з орієнтацією на технологізацію управлінської діяльності. Для формування готовності до застосування технологій педагогічного менеджменту було задіяно потенціал таких навчальних дисциплін: «Теорія та менеджмент освітніх організацій», «Інформаційно-цифрові техноло- 
гії в освіті та науці», «Психологія управління», «Маркетинг на ринку освітніх послуг», «Моніторинг якості освіти», «Кадровий менеджмент», «Педагогічна комунікація».

3. Впровадження авторської навчальної дисципліни «Технології педагогічного менеджменту», яка спрямована на цілісне формування готовності майбутнього керівника $33 \mathrm{CO}$ до застосування технологій педагогічного менеджменту.

4. Розширення змісту управлінської практики через включення в іiї зміст індивідуальних завдань із технологізації управлінської діяльності.

5. Доповнення тематики кваліфікаційних робіт магістра проблемами застосування технологій педагогічного менеджменту в З3СО [1, с. 256-257].

Особливості досліджуваної ОПП сформульовані наступним чином: про-грама реалізує підготовку сучасних менеджерів у системі освіти, здатних до швидкої адаптації, мобільності та гнучкості стосовно викликів сучасного ринку освітніх послуг; здатних не лише застосовувати існуючі технології педагогічного менеджменту, але й на засадах сучасних наукових досягнень розробляти нові.

Орієнтуючись на завдання управлінської діяльності в сфері освіти, нами визначені загальні та фахові компетентності. Зокрема, до переліку фахових компетентностей ми включили управлінсько-технологічну компетентність - здатність до ефективної технологізації управлінської діяльності в закладі освіти. Вона визначається володінням технологіями педагогічного менеджменту, вмінням оптимізувати процес управління, в тому числі, здійснити оптимальний вибір технологій педагогічного менеджменту та умінням їх ефективно застосовувати в управлінській діяльності в закладі освіти.

Щодо результатів навчання, які характеризують сформованість готовності майбутніх керівників до застосування технологій педагогічного менеджменту нами виділено наступні: знати про сучасні тенденції управлінської діяльності у сфері освіти; розуміти актуальність та необхідність застосування технологій педагогічного менеджменту в сучасному закладі освіти; володіти теоретичними основами системи технологій педагогічного менеджменту; знати особливості та алгоритми реалізації технологій педагогічного менеджменту; володіти навичками реалізації провідних технологій педагогічного менедж- 
менту; критично оцінювати потенційні можливості технологій в реальних умовах закладу освіти.

Також, як зазначалось, здійсненна модифікація змісту навчальних дисциплін загального та професійного циклів інваріативної та варіативної складових ОПП фахової підготовки майбутніх керівників з орієнтацією на технологізацію управлінської діяльності.

У процесі оновлення робочого навчального плану до вибіркової його частини внесено навчальну дисципліну «Технології педагогічного менеджменту». Але, зважаючи на високу актуальність технологізації управлінської діяльності в сучасних закладах освіти, в один варіативний ряд внесені також близькі за змістом вибіркові навчальні дисципліни: «Технології управління закладом освіти» та «Технології управління педагогічними працівниками».

Навчальна дисципліна «Технології педагогічного менеджменту» включає такі змістові модулі: «Технології кадрового менеджменту», «Командоутворюючі технології», «Технології ефективного менеджменту», «Форсайт-технології», «Маркетингові технології», «Антикризові технології».

Розширення змісту управлінської практики реалізувалось через включення в іiі зміст індивідуальних завдань із технологізації управлінської діяльності. Практиканти отримали практичне завдання: розробити і провести в закладі освіти, в якому вони проходять управлінську практику, тренінг з конкретної технології педагогічного менеджменту (на вибір). Таким чином реалізується тісний зв'язок теорії з практикою, магістранти мають можливість застосувати інструментарій обраної технології і перевірити ії на ефективність не в штучно створених, а в реальних умовах закладу освіти.

Також задля досягнення мети нами доповнено тематики кваліфікаційних робіт магістра проблемами застосування технологій педагогічного менеджменту в 3ЗСО. Майбутні керівники досліджують такі теми: «Особливості реалізації технологій педагогічного менеджменту в закладі освіти», «Технологічне забезпечення системи формування готовності майбутнього керівника закладу освіти до стратегічного управління в умовах магістратури», «Педагогічні умови формування готовності майбутніх керівників закладів освіти до технології адаптивного управління», «Особливості формування готовності майбут- 
ніх керівників закладів освіти до застосування коучинг-технології», «Педагогічні умови формування готовності майбутнього керівника закладу освіти до застосування технології антимобінгу», «Педагогічний моніторинг як інструмент управління освітнім процесом» тощо.

Отже, забезпечення формування готовності майбутнього керівника до застосування технологій педагогічного менеджменту визначалось: врахуванням змісту та основного призначення конкретної авторської навчальної дисципліни («Технології педагогічного менеджменту»), орієнтованої на технологізацію управлінської діяльності в закладі освіти; забезпеченням потужних міждисциплінарних зв'язків та інтеграції задля формування готовності випускника магістерської програми до застосування технологій педагогічного менеджменту; включенням у процес формування готовності майбутнього керівника управлінської практики та науково-дослідної роботи.

Зміни, запропоновані у змісті системи підготовки майбутнього керівника 33СО в умовах магістратури, дають можливість сформувати в нього на належному рівні готовність до застосування технологій педагогічного менеджменту.

\section{5. Процесуальний блок системи підготовки}

Процесуальний блок системи підготовки майбутнього керівника до застосування технологій педагогічного менеджменту характеризується цілісністю та системністю освітнього процесу в умовах магістратури, забезпеченням участі здобувача в усіх видах діяльності (навчальній, професійно-адаптивній та дослідницькій). Реалізується через застосування в системі підготовки технологій навчання та діагностики, які впливають на мотивацію майбутнього керівника, розуміння ним ролі i місця технологій педагогічного менеджменту в управлінській діяльності, стимулюють його активну навчально-пізнавальну діяльність, підвищують інтерес до обраного фаху.

Технології навчання розглядаються нами як цілеспрямована сукупність методів, форм та засобів, які застосовують науково-педагогічні працівники ЗВО в освітньому процесі задля його оптимізації. Всезростаючий інтерес до технологій навчання пов'язуємо із можливостями вилучення із навчання малоефективних вербальних способів передачі знань та створення реальних умов для самоактулізації і самореалізації 
здобувача, із потребою забезпечення спільної діяльності викладача та здобувача.

Провідними технологіями навчання, які використовуються викладачами ЗВО для формування здатності майбутніх керівників до застосування технологій педагогічного менеджменту є: дискусійні, тренінгові, інформаційно-цифрові (в тому числі, дистанційні, хмарні, смарт-технології), проєктні, технології ситуативного моделювання, проблемного навчання. Означені технології навчання реалізуються в процесі проведення лекційних, практичних занять та організації самостійної роботи. Використовуються також і в професійно-адаптивній та дослідницькій діяльності (під час проходження управлінської практики та здійснення науково-дослідної роботи), де переважають технології ситуативного моделювання, інформаційно-цифрові, тренінгові та проєктні технології.

Для 3'ясування рівня ефективності технологізації управлінської діяльності в реальних умовах 33СО здобувачами в професійно-адаптивній та дослідницькій діяльності використовується технологія діагностування. Технологію діагностики в педагогічному менеджменті визначаємо як діяльність з виявлення актуального стану і тенденцій в управлінській діяльності закладу освіти, актуальних технологій педагогічного менеджменту, які спрямовані на успішне та ефективне управління закладом освіти. Технологія діагностики представлена сукупністю методів.

Найчастіше майбутніми керівниками використовуються такі методи діагностування: спостереження, анкетування, тестування, соціометричне дослідження, бесіда, інтерв'ювання, вивчення продуктів діяльності, метод експертних оцінок, контент-аналіз, статистичний аналіз тощо.

Реалізація процесуального блоку повинна забезпечити: створення умов для здобуття майбутніми керівниками знань про педагогічний менеджмент та його актуальні технології в умовах 33СО; організацію цілеспрямованого, планомірного, систематизованого та послідовного формування у майбутнього керівника $33 \mathrm{CO}$ готовності до застосування технологій педагогічного менеджменту; відтворення управлінсько-технологічної діяльності керівника через використання викладачем ЗВО технологій навчання в процесі проведення лекційних, 
практичних занять, організації самостійної роботи, в процесі проходження управлінської практики та здійснення науково-дослідницької діяльності; здатність до перевірки технологій педагогічного менеджменту на ефективність через використання технології діагностики; формування управлінсько-технологічної компетентності в умовах аудиторної (лекційних, практичних занять) та позааудиторної роботи (самостійної роботи, науково-дослідницької діяльності, управлінської практики).

\section{6. Контрольний блок системи підготовки}

Завершальним компонентом у впровадженні системи підготовки майбутнього керівника до застосування технологій педагогічного менеджменту є контрольний блок. Він відтворює досягнення поставленої мети, тобто кінцевий результат процесу системи підготовки майбутнього керівника до застосування технологій педагогічного менеджменту - сформованість означеної готовності. Контрольний блок спрямований на визначення ефективності функціонування всієї моделі системи підготовки майбутнього керівника до застосування технологій педагогічного менеджменту, визначення результативності дій кожного ії компоненту.

Даний блок забезпечує оцінювання готовності майбутнього керівника до застосування технологій педагогічного менеджменту за критеріями, показниками, рівнями та за допомогою діагностування.

Відповідно до структури досліджуваної готовності нами були виділені мотиваційно-ціннісний, когнітивний, технологічний, особистісний та рефлексивний критерії, які дають змогу визначити рівень сформованості готовності майбутніх керівників 33СО до застосування технологій педагогічного менеджменту.

Мотиваційно-ціннісний критерій характеризує рівень сформованості професійної спрямованості особистості майбутнього керівника 33СО: інтерес до управлінської діяльності; бажання займати керівні посади; мотивація досягнення успіху в управлінській діяльності; усвідомлення значущості технологій в педагогічному менеджменті.

Когнітивний критерій характеризує рівень засвоєння теоретичних знань 3 технологій педагогічного менеджменту: володіння системою знань, необхідних для ефективного педагогічного менеджменту та 
технологізації управлінської діяльності в закладі освіти; розуміння сутності, цілей та завдань, змісту та специфіки різних технологій педагогічного менеджменту; знання алгоритму реалізації конкретної технології педагогічного менеджменту; обізнаність із інструментарієм технологій педагогічного менеджменту; знання показників та методів діагностики ефективності технологій.

Технологічний критерій характеризується здатністю застосовувати технології педагогічного менеджменту в управлінській діяльності. Показниками цього критерію є: сформованість комплексу управлінських умінь (організаторських, прогностичних, конструктивних, комунікативних, когнітивних, рефлексивних); здатність застосовувати на практиці сучасні технології педагогічного менеджменту; володіння інструментарієм та алгоритмом реалізації технологій педагогічного менеджменту; наявність уміння здійснювати оптимальний вибір технологій педагогічного менеджменту та відповідного інструментарію.

Особистісний критерій характеризується наявністю професійно важливих особистісних якостей, які впливають на результат управлінської діяльності в 3ЗСО. Показниками цього критерію $є$ рівень сформованості професійно важливих та необхідних для здійснення ефективної управлінської діяльності якостей (морально-етичних, лідерських, організаторських, комунікативних тощо).

Рефлексивний критерій характеризує рівень здатності майбутнього керівника до самоконтролю, самовдосконалення та самооцінки. Його показниками $є$ : вміння критично оцінювати і аналізувати власну адаптивно-управлінську діяльність (самодіагностика); здатність корегувати власні недоліки; прагнення до підвищення управлінсько-технологічної компетентності, саморегуляції, самовдосконалення та саморозвитку.

Нами виділено три рівні готовності майбутніх керівників $33 \mathrm{CO}$ до застосування технологій педагогічного менеджменту:

Низький рівень готовності майбутніх керівників $33 \mathrm{CO}$ до застосування технологій педагогічного менеджменту передбачає неповне розуміння сутності та цілей технологізації управлінської діяльності, слабку орієнтацію в іiі завданнях, класифікації технологій. Професійно важливі знання з педагогічного менеджменту носять хаотичний, поверховий, нестійкий та несистематизований характер. Майбутні керівники неповною мірою розуміють сутність, зміст та специфіку 
різних технологій педагогічного менеджменту. Мають приблизне уявлення про алгоритм реалізації конкретної технології педагогічного менеджменту. Слабка обізнаність із інструментарієм технологій педагогічного менеджменту; показниками та методами діагностики ефективності технологій.

Відповідно, низький рівень готовності майбутніх керівників також проявляється в недостатньому розумінні необхідності застосовувати в управлінській діяльності сучасних технологій педагогічного менеджменту.

Поверхова обізнаність із змістом, інструментарієм та алгоритмом реалізації технологій педагогічного менеджменту, невміння здійснювати їх оптимальний вибір, призводить до значної кількості недоліків при застосуванні. Відтак, для низького рівня готовності притаманна недостатня розвиненість професійно важливих особистісних якостей, які впливають на результат управлінської діяльності в 33СО.

Майбутні керівники 3 низьким рівнем готовності до застосування технологій педагогічного менеджменту не виявляють зацікавленості в управлінській діяльності та не усвідомлюють ії значущості; не бачать необхідності в професійному зростанні, самовдосконаленні та саморозвитку; мотивація та пізнавальна зацікавленість слабо виражені. Професійно важливі особистісні якості (зокрема, лідерство, комунікативність, витривалість, емоційна стійкість), розвинені недостатньо. При цьому наявна неадекватна, як правило, завищена, самооцінка рівня своєї управлінсько-технологічної компетентності.

Середній рівень готовності майбутніх керівників $33 \mathrm{CO}$ до застосування технологій педагогічного менеджменту характеризується неповним розумінням сутності та цілей технологізації управлінської діяльності, часткою орієнтацією в іiі завданнях, класифікації технологій. Професійно важливі знання 3 педагогічного менеджменту частково систематизовані. При цьому, наявне недостатньо глибоке розуміння суті, змісту та специфіки різних технологій педагогічного менеджменту. Мають часткове уявлення про алгоритм реалізації конкретної технології педагогічного менеджменту. Неповна обізнаність із інструментарієм технологій педагогічного менеджменту, показниками та методами діагностики ефективності технологій, що призводить до недостатньої точності та наявності незначної кількості недоліків при їх реалізації. 
Відповідно, середній рівень готовності майбутніх керівників проявляється у частковому розумінні місця, ролі та важливості застосування в управлінській діяльності сучасних технологій педагогічного менеджменту.

Часткова обізнаність із змістом, інструментарієм та алгоритмом реалізації технологій педагогічного менеджменту, обмежена здатність здійснювати їх оптимальний вибір. У типових та нетипових змодельованих ситуаціях майбутні керівники демонструють здатність до репродуктивного відтворення, діють за зразком, креативний підхід слабо виражений.

Також притаманна недостатня розвиненість професійно важливих особистісних якостей, які впливають на результат управлінської діяльності в $33 \mathrm{CO}$.

Зацікавленість у майбутній управлінській діяльності ситуативна, проявляється неповне усвідомлення іiі значущості та суперечливе ставлення до професійного майбутнього. Прагнення до самовдосконалення, саморегуляції, саморозвитку та професійного зростання, розвинені недостатньо і мають несистематичний характер. Пізнавальний інтерес та мотивація є нестійкими. Самооцінка рівня своєї управлінсько-технологічної компетентності не завжди адекватна (занижена або завищена).

Високий рівень готовності майбутніх керівників $33 \mathrm{CO}$ до застосування технологій педагогічного менеджменту передбачає глибоке розуміння сутності та цілей технологізації управлінської діяльності, чітку орієнтацію в ії завданнях, класифікації технологій. Професійно важливі знання з педагогічного менеджменту стійкі та систематизовані. Майбутні керівники розуміють суть та специфіку, володіють змістом різних технологій педагогічного менеджменту. Знають чіткий алгоритм реалізації конкретної технології педагогічного менеджменту. Даний рівень характеризується обізнаністю здобувачів із інструментарієм технологій педагогічного менеджменту; показниками та методами діагностики ефективності технологій.

Відтак, обізнаність із змістом, інструментарієм та алгоритмом реалізації технологій педагогічного менеджменту, вміння здійснювати їх оптимальний вибір, призводять до вправного застосування означених технологій в адаптивно-управлінській діяльності. У типових та 
нетипових змодельованих ситуаціях майбутні керівники демонструють здатність самостійно відтворювати визначену послідовність та систему дій. Спостерігається також створення власних способів, алгоритмів реалізації технологій, формулювання оригінальних рішень в контексті управлінської діяльності.

Професійно важливі особистісні якості (гуманність, толерантність, комунікативність, асертивність, стресостійкість, впевненість у собі, відповідальність, цілеспрямованість, харизматичність, товариськість тощо), які впливають на результат успішної управлінської діяльності в З3СО розвинені на високу рівні.

Даний рівень виражається позитивним ставленням до управлінської діяльності, наявністю стійких мотивів у підвищенні управлінсько-технологічної компетентності, постійним прагненням до самовдосконалення та саморозвитку. Наявне стійке бажання досягти високих професійних результатів та кар'єрного зростання. Професійно важливі особистісні якості повністю сформовані (зокрема, готовність до співпраці та взаємодопомоги, здатність реально оцінювати ситуацію, адаптуватися до виробничих обставин тощо). Майбутні керівники демонструють високу працездатність, ініціативність та впевненість у власних управлінських здібностях. Спостерігається адекватна самооцінка управлінсько-технологічної компетентності.

Контроль рівня сформованості управлінсько-технологічної компетентності у майбутніх керівників проводиться з метою визначення здатності здобувачів до застосування в З3СО технологій педагогічного менеджменту та дозволяє отримати кількісні показники якості процесу навчання; визначити ефективні технології навчання; активізувати теоретичні знання 3 технологій педагогічного менеджменту; формувати уміння та навички з технологізації управлінського процесу, спрогнозувати шляхи успішного оволодіння технологіями педагогічного менеджменту в умовах магістратури.

Пропонуємо двосторонню систему контролю рівня сформованості майбутніх керівників готовності: контроль викладача (вхідний, поточний, проміжний, підсумковий) - дозволяе коригувати процес формування готовності в залежності від отриманих результатів навчання; контроль здобувача самого себе - самоконтроль або рефлексивний контроль. 
Отже, належно організований контроль успішності дозволить викладачеві ефективно управляти навчальною діяльність 3 формування управлінсько-технологічної компетентності майбутніх керівників $33 \mathrm{CO}$ та сприятиме успішному оволодінню технологіями педагогічного менеджменту. На основі даних контролю здійснюється адаптація та коригування системи підготовки майбутніх керівників.

\section{7. Висновки}

У публікації представлено структурно-функціональну модель системи підготовки майбутніх керівників до застосування технологій педагогічного менеджменту, окреслено основні структурні блоки та характер їх взаємодії.

3'ясовано, що цільовий блок представленої моделі є системоутворюючим, оскільки відображає мету та провідні завдання системи підготовки майбутніх керівників 33СО, які слугують основою при визначенні змісту, організаційних форм, методів та засобів формування готовності до застосування технологій педагогічного менеджменту в умовах магістратури. Методологічний блок, в свою чергу, розкриває систему однойменних підходів та принципів (загальнодидактичних та специфічних), які стали науковим підгрунтям для визначення та впровадження педагогічних умов, структурування змісту системи підготовки майбутніх керівників до застосування технологій педагогічного менеджменту, оптимального вибору форм, методів та засобів навчальної діяльності. Змістовий блок визначається освітньою програмою, навчальними планами, програмами, підручниками, посібниками, сучасними науковими концепціями і методичними розробками 3 технологій педагогічного, які є основними для формування здатності у майбутніх керівників до застосування технологій педагогічного менеджменту. Процесуальний блок характеризується цілісністю та системністю освітнього процесу в умовах магістратури, забезпеченням участі здобувача в усіх видах діяльності. Реалізується через застосування в системі підготовки технологій навчання та діагностики. Контрольний блок відтворює досягнення поставленої мети, тобто кінцевий результат процесу системи підготовки майбутнього керівника до застосування технологій педагогічного менеджменту - сформованість означеної готовності. 
Пропонована модель відповідає виявленим тенденціям до узгодження змін у професійній діяльності та змісту професійної освіти на прикладі підготовки майбутніх керівників 33СО до застосування технологій педагогічного менеджменту.

Представлена модель може розглядатися як основа своєрідної стратегії професійної освіти в умовах магістратури, але разом із тим, ефективність іiі застосування необхідно перевірити в експериментальній частині дослідження для подальшого осмислення і коригування.

\section{Список літератури:}

1. Лебідь О.В. Система формування готовності майбутнього керівника загальноосвітнього навчального закладу до стратегічного управління в умовах магістратури. Вісник Університету імені Альфреда Нобеля. Серія : Педагогіка і психологія. 2019. № 1. С. 252-262.

2. Сас Н. Модель професійної підготовки майбутніх керівників навчальних закладів до інноваційного управління. Ukrainian professional education. 2017. Вип. 1. С. 62-73.

3. Улановська А.С. Модернізація вищої освіти: характеристика понятійного апарату дослідження. Педагогічні науки: теорія, історія, інноваиійні технологіï. 2014. № 1(35). С. 260-270.

4. Чеботарьов М.К. Готовність майбутніх менеджерів до адаптивного управління: сутність, структура, механізми і детермінанти іiі формування. Педагогіка і психологія професійної освіти. 2014. № 2. С. 69-77.

5. Швардак М.В. Контент-аналіз освітніх програм підготовки майбутніх керівників закладів освіти. Вісник Кременчуиького національного університету імені Михайла Остроградського. 2020. № 4(123). С. 9-16.

6. Швардак М.В. Сучасні методологічні підходи формування готовності майбутніх керівників закладів освіти до застосування технологій педагогічного менеджменту. Вісник ЛНУ імені Тараса Шевченка. 2020. Листопад. № 5(336). С. 184-195.

7. Щодо рекомендацій з академічної доброчесності для закладів вищої освіти. 23.10.2018 № 1/9-650. URL: https://zakon.rada.gov.ua/rada/show/ v-650729-18\#Text (дата звернення: 15.11.2020).

8. Ягупов В. Моделювання навчального процесу як педагогічна проблема. Неперервна професійна освіта: теорія $і$ практика : науково-методичний журнал. Київ : МДГУ, 2003. Випуск 1. С. 28-37.

\section{References:}

1. Lebidj O.V. (2019). Systema formuvannja ghotovnosti majbutnjogho kerivnyka zaghaljnoosvitnjogho navchaljnogho zakladu do strateghichnogho upravlinnja $\mathrm{v}$ umovakh maghistratury [System of formation of development of future heads' of general educational institution readiness for strategic management 
in master's degree courses]. Visnyk Universytetu imeni Aljfreda Nobelja. Serija: Pedaghoghika i psykhologhija, vol. 1, pp. 252-262.

2. Sas N. (2017). Modelj profesijnoji pidghotovky majbutnikh kerivnykiv navchaljnykh zakladiv do innovacijnogho upravlinnja [Model of professional training of future heads of educational institutions for innovation management]. Ukrainian professional education, vol. 1, pp. 62-73.

3. Ulanovsjka A.S. (2014). Modernizacija vyshhoji osvity: kharakterystyka ponjatijnogho aparatu doslidzhennja [Modernization of higher education: characteristics of the conceptual apparatus of research]. Pedaghoghichni nauky: teorija, istorija, innovacijni tekhnologhiji, vol. 1(35), pp. 260-270.

4. Chebotarjov M.K. (2014). Ghotovnistj majbutnikh menedzheriv do adaptyvnogho upravlinnja: sutnistj, struktura, mekhanizmy i determinanty jiji formuvannja [Readiness of future managers for adaptive management: essence, structure, mechanisms, and determinants of its formation]. Pedaghoghika i psykhologhija profesijnoji osvity, vol. 2, pp. 69-77.

5. Shvardak M.V. (2020). Kontent-analiz osvitnikh proghram pidghotovky majbutnikh kerivnykiv zakladiv osvity [Content analysis of educational programs for training future heads of educational institutions]. Visnyk Kremenchucjkogho nacionaljnogho universytetu imeni Mykhajla Ostroghradsjkogho, vol. 4(123), pp. 9-16.

6. Shvardak M.V. (2020). Suchasni metodologhichni pidkhody formuvannja ghotovnosti majbutnikh kerivnykiv zakladiv osvity do zastosuvannja tekhnologhij pedaghoghichnogho menedzhmentu [Modern methodological approaches to the formation of readiness of future heads of educational institutions to apply the technologies of pedagogical management]. Visnyk LNU imeni Tarasa Shevchenka, vol. 5(336), pp. 184-195.

7. Shhodo rekomendacij $\mathrm{z}$ akademichnoji dobrochesnosti dlja zakladiv vyshhoji osvity [Regarding recommendations on academic integrity for higher education institutions] (2018), no 1/9-650. Retrieved from: https://zakon.rada.gov.ua/ $\mathrm{rada} / \mathrm{show} / \mathrm{v}-650729-18 \#$ Text (accessed: 15.11.2020).

8. Jaghupov V. (2003). Modeljuvannja navchaljnogho procesu jak pedaghoghichna problema [Modeling of educational process as a pedagogical problem]. Neperervna profesijna osvita: teorija i praktyka: naukovo-metodychnyj zhurnal, vol. 1 , pp. 28-37. 